\title{
The Disintegration of Yugoslavia (1989-2001)
}

\section{Dr.sc Fati Iseni}

Fati.iseni@yahoo.co.uk

Doi:10.5901/mjss.2014.v5n6p403

\begin{abstract}
The fragile state so-called "Yugoslavia" had already begun to decay from within itself during the past decade because of many factors, but mostly from ethnic conflicts. Among other nations who were not satisfied with its constitutional order and the Serbian chauvinist aggression were Slovenes, Croats and Albanians. Unlike the others, Albanians were the only ones who dared to challenge the very strong political and military system of the federation that was built with decades. The reasons were numerous. Already for many years Serbian and Yugoslav governments under the umbrella of Milosevic were perpetrators of continued violence over the entire Albanian population in Yugoslavia. The Albanian question in Yugoslavia despite Milosevic's government attempts to remain as an internal issue of Yugoslavia (or Serbia and Macedonia), it was still found very soon in the round tables of the major world powers who would later be the most powerful advocates of Albanians in their pathway for their freedom and independence.
\end{abstract}

Keywords: Discrimination, aggression, freedom, hegemony, irredentist, demonstrations, mistreatment, communists, security structures, political dialogue, communities, ethnic tensions, violence.

\section{The Disintegration of Former Yugoslav Federation and the Albanian issue}

The Political concept "Cold War", will be broken in the late 80's and early 90's, with the unification of Germany and the dissolution of the Soviet Union. The entire investment in the intelligence services and military arsenal, would be put under review and will began the redefinition of political lines in the global level, relocating them completely in other political coordinates. Throughout these major changes in the global policy atrium, Tito's Yugoslavia will also be withdrawn into it. Unlike the peaceful political divorce of several countries of the former Soviet Union, which were under its influence such as the Czech Republic and Slovakia, Azerbaijan, Tajikistan, Uzbekistan, etc. In Former Yugoslavia, political developments took different directions.

Certainly the echoes of the great changes toward democratization of the political system in Central and Eastern Europe, had also covered the Balkans, Yugoslavia, Bulgaria and Albania later. ${ }^{1}$ In this context seen the hope of Albanians in Yugoslavia, to be given the opportunity to advance their political status. In Yugoslavia, as in the Soviet Union, along with movements for change in the political system, also will appear the first signs that the local Federation want to secede and seek independence, but this political divorce will be accompanied by bloody war. ${ }^{2}$ The first to break off from Yugoslavia was Slovenia, then Croatia and soon followed this path Bosnia and Herzegovina and Macedonia. ${ }^{3}$

Meanwhile Montenegro, still following the pro-Serbian policy, as its leader Momir Bulatovic, was closely linked to Milosevic. Although Kosovo, despite the fact based on the 1974 Constitution of Yugoslavia which was the constituent part of the Federation, including the right to secede, though abrogating all laws by Serbia such as the right Kosovo to declare independence was violently taken off. Unlike other federal entities, Kosovo will be exposed to a wild curfew by Milosevic and Albanian hopes to pursue political changes in this part of Europe would be too limited. Although the issue of the dissolution of Yugoslavia was part of world's macro-politics that were staying silent when the process was going on, even though there were some voices who still gave support to Yugoslavia, but also different analysts questioning the sustainability and stability of republics, since they can be violent from within itself. ${ }^{4}$

Tito's conglomerate state, which tried to transform into a state model in front of - Western capitalist world, also even in front of those socialist and Muslim worlds, as an example of the coexistence of many nations and religions, will soon collapse like house of cartons. Over the past decades, all negative energy and the mutual hatred that was

${ }^{1}$ Norman Davies, Europe a History, Pimlico, London, 1997, f. 1134.

2 Mark Mazover, The Balkans, Phoenix Press, London, 2000, f.134.

3Sylë Ukshini, Kosova në politikën e jashtme të BE-së 1991-2007, Logos-A, 2008, Shkup, Tiranë, Prishtinë. f.20.

${ }^{4}$ Cyril Buffet and Beatrice Heuser, Haunted by History, Brghahn Books Providence Oxford, 1998, f.16. 
accumulated in the name of unity and false brotherhood would explode with a tremendous force, creating more front- line of fighting, in the territory that once pervaded the Tito's relay. Within this artificial creature, was included part of the Albanian nation, that remained under Yugoslavia since 1945. The Albanians in the former Yugoslavia, by the number of inhabitants were ranked as a third nation, while for the political treatment, social and economic, of course they were listed the last.

At the time of its dissolution, the important thing was the way of treatment of Albanians by Yugoslav policy makers, basically Serbians and Macedonians respectively, because these two nations had "troubles" with Albanians. While in Yugoslavia other nations in the Federation began the process of independence which was followed by terrible fighting that brought restlessness to the entire international community. The Albanians, again underwent a new occupation, namely in Kosovo and in Presevo valley, which Serbians consider as their own properties, while the rest of Albanians remained under Montenegro and Macedonia. ${ }^{5}$

Albanians would consider this political move as a classic neo-colonialism which would represent a new challenge for them to find a way for freedom. Although, the process of internationalization of the Albanian issue seemed to go very slow, however it was found on the world's political rounding tables, in Washington, Brussels and New York.

At the end of the ninth decade of the XX century, political and social situation throughout Central and Eastern Europe was boiling. Almost in all countries throughout the socialist bloc situation was deteriorating every day. Certain freedom political structures among Central and East Europe, firstly under cover than openly had the courage not only organizing active resistance against the communist dictatorial power, but also managed to convince the masses very quickly and seriously challenged the dictatorship power. As a result many dictators were thrown out of power one by one in Communist countries of Central and East Europe.

In South Eastern Europe, very soon was reflected this popular movement and began the democratization processes of the political system in these states. Therefore in the former Yugoslav Federation, consisting of different people, grievances were very high. Firstly, because the Serbian hegemony spreading in all parts of the federation, especially after climbing to power of Slobodan Milosevic. Second, reactions and demands for reform came from all sides of the Federation, but the Slovenes and Croats were most outspoken in this regard. It is worth mentioning that the Albanians were the first in the Yugoslav federation that dared to challenge the state dictatorship system, by expressing their grievances in public protests and demonstrations as in 1981, and in 1987, demanding greater freedom and equality in every field between peoples in federation.

Political changes and reforms in the political system in Romania after the tragic events in the fall of 1989, the overthrow of Ceausescu from power, shooting him and his wife, had an impact on the former Yugoslavia, these events were followed with close attention by Yugoslav authorities.

Despite the security measures taken by all political and military suite of Yugoslavia, giving maximum effort to establish control upon communist leadership of the republics and provinces as a constitutive part of the Yugoslav federation, it is already late as few leaders are openly opposing the Serb hegemony. In this context, Milosevic with the help of the Yugoslav Army commander, Veljko Kadijevic, intended to discipline the communist leaders of other federal entities to gain absolute control over the federation, thus trying to prevent their secessionist attempts, a movement that was more appeared in Slovenia, Croatia and Kosovo.

Feeling the pressure of Serbian monopoly and financial crises that the rest of Federation got stuck in, Slovenes and Croatian considered they had scored a much bigger developing economic achievement and not depending on other federal entities and they had remained hostage of regressive processes for two decades, so they aim to get out of this federation controlled recently by Serbs. While people of Kosovo considered that they were suppressed for decades by Serbs and exploited economically by them. During recent years Serbia threatens the political status of Kosovo and also oppressed Albanians in Macedonia, Serbia and Montenegro. Therefore Albanians seeking more advanced status within the federation including the right to secede same as the other republics had the right for such a political move.

The Serbian policy of establishing control over federation proved unsuccessful. From eight federal units Milosevic managed to take control over: Serbia, Montenegro, Kosovo and Vojvodina. The more dictatorship was applied by Milosevic to other parts of Federation, the frustration was higher against the Serbs and Milosevic. The political eruption will break the momentum in an uncontrolled manner in Slovenia, Croatia, Kosovo and Bosnia, during 1990 - 92. This situation is aggravated excessively for Albanians in Kosovo and Macedonia, as Serbia installs political and military state apparatus upon them.

The late 80's in the Former Yugoslavia are characterized by numerous of specifications in the state policy level. During that time not only the Albanians demanded political reorganization of the Federation, but also other nations were

5Jusuf Zejnullahu, Stuhi lufte mbi Kosovë, Botimet Toena, Tiranë, 2007, f. 222. 
interested for such a political reform. Climbing to power of Slobodan Milosevic from 1986-87 marks the raising up of inter - ethnic tensions throughout the Yugoslav Federation ranging from Slovenians, Croats, Bosnians and down to the Macedonians, especially between the Serbs and Albanians.

On top of the joint state that was built for decades, stood the uncontested figure of Tito no matter whether he was alive or after his death up to 1987. It took only few months during 1987 that the Federation slipped off on the hands of anonymous Yugoslav politician so called Slobodan Milosevic, a banker in his middle age and he was characterized by his aggressive attitude to all the senior staff of the Yugoslav Federation. The new Serbian leader began to ruins all of that was built by Tito and his staff since 1941 onwards. The reputation in the international sphere and inter-ethnic relations were quite important to keep a balance between ethnic communities living in the federation. Greater aggressiveness he will show toward the Albanians in Kosovo and in general in all other Republics where they used to live. By reviving the Serbian nationalist feelings he slowly but surely created the impression that Albanians allegedly threatened Serbian population in Kosovo. ${ }^{6}$ Milosevic's visit to Kosovo on 28 June 1989 and his speech in front of around a million Serbs, in offensive and threatening tone towards Albanians, indicated that the federation with this leader of the Serbian Communist Party won't be the same. ${ }^{7}$ Milosevic during his speech also stressed out that Serbs in the past had fought for their rights and also this fight should not be excluded in the future. ${ }^{8}$ Serbian hegemony was quite visible in the territory of former Yugoslavia, but in the late 80 s already culminated in a larger scale.

Repressive measures that are now taken by the Serbian regime headed by Milosevic against Albanians, not only returned back to the situation of the 1981, when student demonstrations being suppressed violently and draconian sentences were given to the Albanian youth. Violence and terror will affect every sphere of life of the Albanians, starting from economical to their educational and political ones. The position of Albanians in Yugoslavia in the Constitution of 1974 will be advanced significantly, especially Kosovo's status would rise up to the equal unit same as to the other republics and provinces in Yugoslavia. ${ }^{9}$ It is important to underline that effort of Albanians to advance their political position within the federation because of repression by Yugoslavia, the Albanian State and the communist leader Enver Hoxha were accused by Yugoslavs that they allegedly are behind the so called "contra-revolution in Kosovo".

The propaganda was very high toward Albania by the Yugoslav authorities and by Albanian individuals who were incriminated in Yugoslav politics and they have forgotten that they belong to Albanian nation, representing them and also those senior political position that they held in the Yugoslav state hierarchy are on behalf of them. One of the highest Albanian officials in the federation will emphasize "...The creation of the Albanian Republic in Yugoslavia, according to Enver Hoxha, it is just a first stage for the realization of his irredentist dream for the secession of Kosovo from Yugoslavia and its union with Albania. The fall of the Yugoslav Federation (created in the socialist revolution, its Republics does not match their national structure of the population within the territory, as they are ethnically mixed up and live out of their Republics, such as the case with the Socialist Autonomous Province of Kosovo ) and changing of state borders, are not possible to realize without use of force, contra-revolutionary demonstrations slogan emphasized that the Albanian Republic in Yugoslavia would be achieved <peacefully or forcefullys. From this point of view, one can conclude that Enver Hoxha and the Albanian irredentists in Yugoslavia have attempted with their contra-revolutionary goals to bring civil war against Socialist Yugoslav Federation and self-governance." ${ }^{10}$ The concern of the highest state leaders is not accidentally. Certainly it is a reflection of increasing awareness of the Albanians in Yugoslavia and their struggle to improve their political status, but although Republic of Albania showed more interest these recent years for the Albanian population in Yugoslavia. On the other hand the Yugoslav authorities were concerned because it was not just a simple act but this is an indicator for them that Albanian Movement in Yugoslavia had managed to gain access to the most senior leaders of Albania. Through this political channel they would reveal abroad directly the Albanian issue in Yugoslavia and they are going to have access to the international organizations so it will be present in round tables in the main world chancelleries.

The Yugoslav media taking orders from daily politics, will tend to represent the situation in the country and the position of Albanians that occupied in the Yugoslav society and particularly in Macedonia, with the final aim of distorting facts and fumigating the real situation in the country. Based on propaganda of the Yugoslav media, allegedly Albanians enjoy all human rights with particular emphasize that they are citing: primary education where approximately 86,000

${ }^{6}$ Faton Mehmetaj, Veprimtaria kriminale e "Dorës së zezë" serbe në trojet shqiptare, Anatema, Prishtinë, 2004, p. 365

7Sabrina P. Ramet, Balkan Babel, Westview, USA, 2002, p. 56.

8John R. Lampe, Yugoslavia as History, Cambridge University Press, 1996, p. 345.

${ }^{9}$ (Kushtetuta e Krahinës Socialiste Autonome të Kosovës, Rilindja, Prishtinë, 1974, f.8. )

${ }^{10}$ Hajredin Hoxha, Marrëdhëniet Jogosllavo-Shqiptare, Afirmimi i Kombësisë Shqiptare në Jugosllavi\&Nacionalizmi dhe irredentizmi stalianian në Shqipëri, Rilindja, Prishtinë, 1983, f.217. 
students are enrolled; the Albanian newspaper "Flaka e Vëllazërimit"( "The flame of brotherhood"), a few magazines for children and representation of Albanians in some institutions. ${ }^{11}$

"On March 23rd 1989, the Parliament in Pristina was surrounded by tanks and armored vehicles. The Hall was filled with Serb <delegates> from security forces, who voted for the changes of some amendments of the Constitution, even though without the majority votes needed. ${ }^{12}$ On March 28 1989 the Serbian Parliament in Belgrade accepted <Amendments > required. "The revocation of Kosovo's Autonomy in March 1989 by changing some of the constitutional amendments turned back Kosovo's status from a constituent part of the Federation in that of so-called Autonomy within Serbia. ${ }^{13}$

In June 1989, Kosovo's parliament and all institutional structures of the autonomous province that time, will be dissolved violently. ${ }^{14}$ "With these constitutional changes being done (F.I. Milosevic ) path the way for putting relations of subordination between the organs of administration of the Republic of Serbia and its autonomous provinces. With this proposal, the purpose of deepening suspension of power in Kosovo, not only being deprived its autonomous constitutive element of federalism, but also the essence of its political-territorial autonomy." ${ }^{15}$

"Dismissing forcefully Albanians from their work places of State Enterprises, removal from position of the few Albanian officials remained in Kosovo and in Macedonia, the closure of media in Albanian language on July $5^{\text {th }} 1990$ as the Radio Television of Kosovo and the daily Albanian newspaper "Rilindja" which were sacred to the Albanians and also they were very connected to these media. ${ }^{16} \mathrm{Closing}$ down the doors of high schools in Albanian language, especially in Albanian settlements in Macedonia: Skopje, Kumanovo, Tetovo, Gostivar, Diber, Struga and Kercova under the pretext of forming classes of mixed Albanian and Macedonian students, in the name of so-called brotherhood and unity between the nations. ${ }^{17}$ Now in addition to police units of Yugoslav Army began preparations even for military intervention. In the Army starting since 1981 onwards all Albanian officers were almost dismissed by the systematic false processes. ${ }^{18}$ In the late 80s the continued action of ruining the yard walls of Albanian homes without warning, in some cases the lives of citizens were put at risk such as in the village of Aracinovo near Skopje, a landlord was hit and killed instantly by the falling wall while authorities were breaking it by bulldozer.

People are killed so insidious and publicly, as Jashiri Ziber in the village of Gajre was killed in his bedroom in presence of his wife and two children, also in the village of Pallatica Bajram Jahiu was killed by the Macedonian policeman Lazo Zmejkovski in the midday in front of his family and his children. In the High School, "Mosha Pijade" in Tetovo a student was killed in the presence of his friends by a Macedonian policeman, while in another area a young guy was hit and killed by a car, driven by a Macedonian policeman and his body was thrown into the canal. ${ }^{19} \mathrm{It}$ means that the Yugoslav and Macedonian government had gone to far in discriminating Albanians such as the demolition of the walls of house yards, that intended to humiliate Albanians. Their life was not worth it anymore. They were mistreated and killed just for fun everywhere: at home, in the street, during public protests, although in some schools, children were poisoned by some Yugoslav Army poison gas.

This pressure was exercised for their short term political purposes, also for a long term of their political agenda because through this uncertainty and foggy situation that was risen by the Macedonian government, Albanian parents were worried for their children and they will be forced to send away them to the Western Europe countries just of making sure that they are going to be safe and have a better future. It was the only way for parents to take preventive measures for their youths because they had no other instrument. The international community had just started wondering about the Albanian question in Yugoslavia, but they still did not have exact information about the situation in terrain. "Serbia wanted to use Macedonia as a pilot area not only to try and limit the natural demographic growth of the Albanians, but also to reduce their education at all levels and also the perspective of Albanians in Kosovo. Macedonian authorities, both at the Republic level, as well as the municipal level, in areas where Albanians dominate, issued several laws to put pressure on

\footnotetext{
${ }^{11}$ Mlad Borec: 8 . XII. 1988)

12Stefan Karastojanov, Kosova, Serembe, Shkup, 2007, p. 191.

13 Jasminka Udoviçki, \& James Ridgeway, Makthi Etnik i Jugosllavisë, Albin, Tiranë, 1998, p. 60.

${ }^{14}$ Ramë Buja, Çështja e Kosovës dhe shkatërimi i Jugosllavisë, Prishtinë, 2007, p. 80.

${ }^{15}$ Esat Stavileci, Ndryshimet Kushtetuese dhe Likuidimi I autonimomisë, në Çështja e Kosovës një problem historic dhe aktual, Instituti I Historisë - Prishtinë dhe Instituti I Historisë - Tiranë, Tiranë, 1996, p. 294.

${ }^{16}$ Hans Peter Rulliman, Ikje Masive, Tiranë, 1997, p.39 .

${ }^{17}$ Flaka e Vëllazërimit, 5. II. 1989

18Zlobec, Alternativa, May 1990, p. 25.

${ }^{19}$ Verziu, Alternativa, May 1990, p. 52.
} 
Albanian families to reduce the natality." ${ }^{20}$ These measures were the most flagrant violations of individual and collective rights against a nation who was not a majority in Yugoslavia, despite the fact that Albanians were as a third nation in number after the Serbs and Croats. This means that the majority should not override the minority in the name of preserving supposedly constitutional order, as Nelson Mandela writes, also he condemns the principle of rule by the majority. ${ }^{21}$

In this political argument were involved publicly even so called independent intellectual and academics on both sides, Albanian and Serbian (also Macedonian) side to defend the trenches on each side. A well known Albanian Academic from the Kosovo Academy of Science, Recep Qosja was arguing with his counterpart from Macedonian Academy of Science, Gane Todorovski regarding the Albanian issue in Macedonia. Among other national issues, Academic Qosja for antagonisms in Macedonia between Macedonians and Albanians noted that he does not encourage the Albanians to oppose the Yugoslav political system, but the Bureaucracy of Yugoslavia and Macedonian political oppression and deprivation of rights are the main factors that are forcing Albanians to organize public protests as the only democratic and peaceful way of expressing their anger against the state apartheid. ${ }^{22}$ Even Albanian intellectuals found difficulties of responding to violations that were made against them, because authorities immediately took measures against the Albanians and also they were charged for igniting Albanian nationalism and irredentism.

Expulsion of Albanian Youth to Western European countries, in long-term policy was far more dangerous than all others measures taken against this nation by Belgrade and Skopje. This policies aimed at changing the ethnic structures of the population by reducing the number of Albanian citizens and encouraging the Slavs people to replace them in the Albanian settlements was extremely dangerous. This demographic war mostly took place in Macedonia after official statistics were published and figures on them showed disadvantages for Macedonians and on the other side Albanian population was growing rapidly, certainly this situation created anxiety in the Macedonian government.

\section{References}

Constitution of Autonomous Socialist Province of Kosovo, Rilindja, Prishtinë, 1974.

Cyril Buffet and Beatrice Heuser, Haunted by History, Brghahn Books Providence Oxford, 1998.

Faton Mehmetaj, Veprimtaria kriminale e "Dorës së zezë" serbe në trojet shqiptare, Anatema, Prishtinë, 2004.

Hajredin Hoxha, Marrëdhëniet Jogosllavo-Shqiptare, Afirmimi i Kombësisë Shqiptare në Jugosllavi\&Nacionalizmi dhe irredentizmi stalianian në Shqipëri, Rilindja, Prishtinë, 1983.

Hans Peter Rulliman, Ikje Masive, Tiranë, 1997.

Jasminka Udoviçki, \& James Ridgeway, Makthi Etnik i Jugosllavisë, Albin, Tiranë, 1998.

John R. Lampe, Yugoslavia as History, Cambridge University Press, 1996.

Jusuf Zejnullahu, Stuhi lufte mbi Kosovë, Botimet Toena, Tiranë, 2007.

Mark Mazover, The Balkans, Phoenix Press, London, 2000.

Norman Davies, Europe a History, Pimlico, London, 1997.

Ramë Buja, Çështja e Kosovës dhe shkatërimi i Jugosllavisë, Prishtinë, 2007.

Rexhep Qosja, Populli i ndaluar, Shtëpia Botuese Enciklopedike, Tiranë, 1990.

Sabrina P. Ramet, Balkan Babel, Westview, USA, 2002.

Stefan Karastojanov, Kosova, Serembe, Shkup, 2007.

Sylë Ukshini, Kosova në politikën e jashtme të BE-së 1991-2007, Logos-A, 2008, Shkup, Tiranë, Prishtinë.

Esat Stavileci, Ndryshimet Kushtetuese dhe Likuidimi i autonimomisë, në Çështja e Kosovës një problem historic dhe aktual, Instituti I Historisë - Prishtinë dhe Instituti I Historisë - Tiranë, Tiranë, 1996.

Hivzi Islami, Problemet Demografike të Kosovës dhe të trevave të tjera etnike shqiptare, në Çështja e Kosovës një problem historic dhe aktual, Instituti I Historisë - Prishtinë dhe Instituti i Historisë - Tiranë, Tiranë, 1996.

\section{Newspapers and Journals:}

Flaka e Vëllazërimit, Skopje, R. Of Macedonia

Mlad Borec, Skopje, R. Of Macedonia

Alternativa, Ljubljana, R. Of Slovenia

${ }^{20 H i v z i ~ I s l a m i, ~ P r o b l e m e t ~ D e m o g r a f i k e ~ t e ̈ ~ K o s o v e ̈ s ~ d h e ~ t e ̈ ~ t r e v a v e ~ t e ̈ ~ t j e r a ~ e t n i k e ~ s h q i p t a r e, ~ n e ̈ ~ C ̧ e ̈ s h t j a ~ e ~ K o s o v e ̈ s ~ n j e ̈ ~ p r o b l e m ~ h i s t o r i c ~}$ dhe aktual, Instituti I Historisë - Prishtinë dhe Instituti i Historisë - Tiranë, Tiranë, 1996, p. 262.

${ }^{21}$ Repishti, Alternativa, May 1990, p. 83.

22 Rexhep Qosja, Populli i ndaluar, Shtëpia Botuese Enciklopedike, Tiranë, 1990, p.140. 
